Ekonomia - Wroclaw Economic Review 23/1 (2017)

Maria ZI. Stankova*

College of Tourism Blagoevgrad, Bulgaria, 2700 Blagoevgrad,

2 Bregalnitsa Str., e-mail: mzlstan@yahoo.com

Stefan Y. Kirilov

College of Tourism Blagoevgrad, Bulgaria, 2700 Blagoevgrad, 2 Bregalnitsa Str., e-mail: skirilov@abv.bg

\title{
Improving the Quality of Life through Balneotourism Practices: The Bulgarian Experience
}

JEL Classification: Z32, I14

Keywords: balneotourism, balneology, mineral waters, balneological treatment

\begin{abstract}
Improving the Quality of Life through Balneotourism Practices:

The Bulgarian Experience

Balneotourism is a traditional element of Bulgaria's tourist destination image. The use of the healing powers of water, climate and mud deposits can be traced back to the old Thracian tribes that inhabited Bulgarian lands thousands of years ago. Bulgaria can successfully develop balneotourism and boost foreign visitors not only with its available natural resources, but also with great affordability of the health services offered. This is an opportunity to overcome the problem of season dependent tourism, as well as to increase revenues in the sector and the economy. At the same time, balneotourism and the establishment of the national health system allow for a real improvement in the quality of life of all the insured but particularly of people with disabilities.

In that regard, the present paper analyses the origins, development and the current state of balneotourism in Bulgaria. Special attention is paid to defining the terms "balneology" and "balneotourism". There are theoretical issues observed as well as significant aspects of the Bulgarian health system related to the utilization of the balneotourism product. Based on conducted research and analysis, recommendations are made aiming at further development of balneotourism and improvement of the quality of life of people with medical conditions and the disabled.
\end{abstract}

\footnotetext{
${ }^{*}$ Both authors have equally contributed to the writing of the paper.
} 


\section{Introduction}

Balneotourism ${ }^{1}$ is a traditional element of Bulgaria's image as a tourist destination (http://pochivka.com/). The use of the healing qualities of water, climate and mud deposits can be traced back to the Thracian tribes that inhabited the present Bulgarian lands thousands of years ago. Known as skilled healers, the Thracians were familiar with the healing potential of thermal springs and forged consecrated grounds close to them. In later times those traditions were preserved and "the sacred springs of Thrace" gained prominence in the ancient world.

Only a handful of countries in Europe can compete with Bulgaria in the abundance and diversity of geothermal sources with different physico-chemical composition and mud-treatment fields. At present over 550 deposits with 1600 mineral springs are explored, with a total flow of $4900 \mathrm{l} / \mathrm{sec}$. Over the past few years large economic interests have developed in the sector, partly due to several hydrological and geological surveys, enriching and diversifying the country's capacity with some valuable and less covered balneological properties. Prevalent are low-mineralization waters $-66.7 \%$, mineralized waters $-14.4 \%$, and gas waters $-17.9 \%$. Thermal mineral waters are particularly chemically diverse - slightly mineralized, hydrothermal sulfide, chlorine, sodium sour containing fluorine, iron, arsenic, etc. The country's large supplies of high-quality healing mud and peat are valuable natural resources. In addition, significant deposits of beitonite clay were found, with undisputedly proven healing qualities. Special importance should also be assigned to the fact that the majority of Balneo and Spa resources are located in favourable climatic regions which allows for balneological treatment parallel to climatotherapy.

\section{Theoretical framework of research}

Hippocrates of Kos first introduced the benefits of hot mineral water for health treatment and recuperation. During the first Olympic Games athletes used mineral waters to relax and recover after heavy physical exercises. They combined the curative effect of turpentine (daubing their bodies to warm up muscles before the competition) with the healing powers of mineral water. It was again Hippocrates who hypothesized that the cause of all diseases laid in an imbalance of bodily fluids, and to regain that balance a change in environment and exercise was advised, which included bathing, perspiration, walking and massages (Boekstein 2014).

Balneology as a science examines mineral waters, their physico-chemical properties and physiological effects on human organism. The medical application of mineral waters and preventive action are subject to balneotherapy as a subsec-

1 The use of the term "balneotourism" and its spelling are consistent with those adopted by the Bulgarian Association of Balneotourism. 
tion of balneology. Balneology and balneological treatment are complex scientific disciplines, bringing together knowledge from the fields of chemistry, physics, geology, hydrology, meteorology, physiology and a set of clinical and functional-morphological medical disciplines, whose integration aims to clarify the nature and importance of the healing properties of mineral waters.

The core mechanism of Balneological treatment lies in the complex reflex and humoral actions in human organisms. Modern medicine classifies balneology as an active functional rehabilitative non-specific treatment. Based on clinical and experimental research, balneological treatment is applied in a variety of medical conditions at different stages and phases of an illness. The curative powers of water for non-specific therapy cannot, however, replace active medical treatment, but can be used complementarily.

General recommendations for balneological treatment application are related to diseases of the cardiovascular system (without sharply pronounced phenomena of heart failures), hypertensive disease (in absence of crisis and damages to the brain, heart and renal vessels), rheumatism in inactive phase in attenuation of acute phenomena and processes in the endomyocardial layer, inflammatory and traumatic diseases of the central nervous system (post-acute attenuation period and in later stages, when necessary to restore malfunctions), functional disorders of the nervous system (neuroses, limpness), diseases of the gastrointestinal tract, diseases of the female reproductive system, skin diseases, heavy metals intoxication, etc. Treatment is not recommended for all infectious and inflammatory diseases in acute stages, tuberculosis in an active phase, malignant neoplasms, chronic diseases of kidneys with malfunctioning, acute atherosclerosis.

Utilization of mineral waters and other natural resources for the provision of health amenities is defined by the IUOTO (International Union of Official Travel Organizations) as thermal tourism (IUOTO 1973). In this context balneology and balneotourism are a parallel manifestation of health tourism and, as Connel (2011) states, it is a relatively gentle form with a long and unbroken history. From ancient times to the present days humankind has used springs and natural resources (Erfurt-Cooper and Cooper 2009) for health benefits or pleasure. Nowadays, the health tourism sector, as well as balneology and balneotourism, are rapidly growing mostly as a result of "shifts in demographic structures as well as lifestyles, the need for stress reduction among the working population, the shift in the medical paradigm towards prevention and alternative practices" (Laesser 2011).

\section{Research methodology}

The methodology used in the study is comprised of a range of approaches and methods, and relevant opportunities available. It is based on an analysis and comparison of data for balneotourism in Bulgaria, mainly from secondary sources. 
These include a review of available literature (largely in Bulgarian), personal observations, and expertise in the field of balneotourism. The initial information used is primarily a result of observations and direct communication.

The methodological approach is based on descriptive observation, as well as handling of data from official Bulgarian public organizations, such as ministries and national agencies. Based on these, the paper analyzes the origins, process of development and present state of balneotourism in Bulgaria. Scrutinized are theoretical issues as well as important aspects of the Bulgarian health system, connected to the utilization of the balneotourism product.

Also, the paper demonstrates the limitations linked to balneotourism studies — in particular, the small number of publications and analyses published on the topic.

\section{The Bulgarian potential of balneotourism resources}

Bulgaria has over 600 mineral springs, whose water composition is identical to or even excels the world's most famous balneological resorts, such as Baden-Baden and Vichy. Large portions (approximately 80\%) of all mineral waters in Bulgaria are aerothermal - low-mineralized, thermal, radioactive, and rich in trace elements (found in Gorna Banya, Pancharevo, Kniazhevo, Bankya, Varshets, Panagyurishte and several spa springs on the Northern Black Sea coast, Dobrinishte, etc.). New leads found in Northern Bulgaria contain highly-mineralized thermal waters with a rich content of hydrogen sulphide, which has a specific influence on a number of diseases. Water rich in iodine and bromine on the Black Sea coast and the reserves of thermal and highly-mineralized water, rich in sulfides and carbon dioxide on the Southern Black Sea coast, complement the wide range of diverse and well effective specific mineral waters. Compared to other European spa resources, the deposits in the country are characterized by high temperature, allowing their utilization in baths or pools for the treatment of a number of chronic inflammatory processes or degenerative diseases (musculoskeletal disorders, gynecological, liver-biliary and renal diseases, etc.), primarily for their significant anti-inflammatory and pain relieving effect (Едрева 2005).

The most common of the mineral waters - acratothermal - have demonstrated the healing properties for centuries. These are used both for external and internal application through inhalation and irrigation. Due to low mineralization, their components are resorbed very well by the body, and having greater osmotic action, they help remove many trace elements from the organism. These are particularly effective when dealing with disorders and inflammatory processes of the urinary system, gynecological diseases and problems of the musculoskeletal apparatus - they increase the urine volume from the kidneys, help shape the acid- 
-alkaline balance of the body, and fight kidney concernment formation (springs found in Hissar, Gorna Banya, Velingrad, Sofia, Pavel Banya, Varshets, Kyustendil, Sapareva banya, Blagoevgrad, Momin Prohod, etc.). The acratothermals provide curative and preventive action through oligo-elements content as well. Many of these are radioactive, some with significant radioactivity (found at Narechen, Momin prohod, Hissar, Strelcha, Pchelin, etc.), which is a particular stimulator of cellular functions, strengthens the functioning of endocrine glands, reduces allergic reactions, positively affects the state of the autonomic nervous system, helps the cardiovascular system, and causes other beneficial changes in the body.

In recent years the world has seen a jump in the interest in prevention and active holidays. The popularity of balneocenters has been renewed in Europe, primarily due to the fact that along with traditional treatment methods different health therapies are offered. Nowadays, many products offered aim at protecting the health of healthy people. Analyses show that increased life expectancy in the economically developed countries, leads to an increased interest in and importance of balneotourism. The role of adults as users of this specific tourist product also increases.

The Bulgarian Association of Balneotourism (BAB) (http://bab-bg.eu/) was established in 2002 in the town of Pomorie. Detailed information on the use of rehabilitation centers in Bulgaria can be found on the website of the Ministry of Health (https://www.mh.government.bg/).

Also, the law on social integration of people with disabilities ${ }^{2}$, under Art. 42 para. 2, item 4, provides the right to supplement funds for balneotherapy and rehabilitative services once a year to:

— persons with more than $90 \%$ permanent disability;

- children up to the age of 16 , with permanently reduced opportunity for social adaptation;

— the military disabled;

The supplement's amount is up to three times the amount of the guaranteed minimum income (currently \$195), but not more than the actual expenditure according to submitted expense documents. People assisting persons with disability are entitled to a full-size supplement too. The "SHR-SP" Jsc country branches for relaxation and rehabilitation admit the military disabled at a $25 \%$ rate of the overall price for the health service. According to the law, for the military and war disabled and injured, the state budget provides $75 \%$ of the cost, and the remaining $25 \%$ is at the expense of an individual.

Bulgaria can develop spa tourism and attract foreign visitors not only thanks to its natural resources, but also the affordability of the health services offered. This is an opportunity to overcome the problem of season dependent tourism, as well as to increase revenues in the sector and national economy.

2 http://lex.bg/laws/ldoc/2135491478. 
Balneotherapy and spa-related foreign tourism in Bulgaria amounts to, on average, more than 15,000 tourists per year, largely from Greece, France, Germany, Italy and Russia, in resorts such as Devin, Hissar, and Velingrad.

The share of balneotherapy and spa tourism in Bulgaria is around $10 \%$, which means that every tenth tourist is a consumer of this kind of service. According to studies, $23 \%$ of foreign visitors to Bulgaria and over $80 \%$ of Bulgarian tourists associate the country with very good opportunities for spa and balneotourism. According to the data of the Bulgarian Union for Balneology and SPA Tourism po Balneology, $65 \%$ of consumers of tourist balneo and spa services are Bulgarians; $10 \%$ of foreign visitors come from Russia, $5 \%$ from Germany, $5 \%$ from Israel, $10 \%$ are from neighboring countries - Greece, Macedonia (FYROM), Romania, Serbia, Turkey, and 5\% come from other markets (http://www.trud.bg/Article.asp?ArticleId=2045129). European Union citizens can use the balneocenters in Bulgaria for preventive care and rehabilitation, as their national health insurers cover up to $90 \%$ of the cost of procedures and treatments, as well as 13 euro for accommodation. German national insurers require, however, that their patients reside only in facilities that have spa and balneology center certificates. Bulgarian citizens can participate in balneo-treatment programs funded by the National Social Security Institute (NSSI), in the facilities of the Ministry of Health and the NSSI only.

They can use four free therapeutic procedures per day, while the spa program itself can reach up to 10 days. There are 51 sanatoriums in the country which accommodate patients for treatment and recovery programs by the NSSI. The planned budget of the NSSI is over 15 million BGN, and the number of people who can benefit from the treatment and rehabilitation programs is well over 40,000 . The NSSI can cover up to $18 \mathrm{BGN}$ per day towards the cost of accommodation, and up to $5 \mathrm{BGN}$ for food, while the remaining funds are paid by the patient.

The state provisions for spa treatment are clearly established. Every insured person has the right to participate in prevention treatment programs for general diseases, maternity, labor accidents and occupational diseases. They should have insurance for 6 consecutive months prior to therapy and provide a diagnosis for the treatment confirmed by a doctor (http://www.mh.government.bg/bg/ informaciya-za-grazhdani/rehabilitaciya-i-balneoturizm/informaciya-za-polzvane-na-bazite-za-rehabilitaciya/). The programs could also benefit the disabled individuals with the Territorial Expert Medical Commission act before they reach the retirement age. The requirement for paid insurance for 6 consecutive months prior to the rehabilitation therapy does not apply to people with disabilities, accident or occupational disease sufferers. Persons insured for work-related accidents and occupational diseases can use prevention and rehabilitation programs of the NSSI only in the case of a work-related accident or occupational disease. Reservations in sanatoriums are made by the patients themselves, following in- 
formation from the NSSI of the facilities suitable for treatment of their particular diseases. That information can also be provided by the GPs.

The General Practitioner (GP) doctor assesses the patient's need for rehabilitation and issues a medical form in two copies, stating the disease and accompanying diseases, if any, and relevant medical tests. Required documents include identification card, official notice from the employer on paid insurance and all medical records attesting the existence of a disease. In case of an expert opinion from the Territorial Expert Medical Commission for group disability or decision for occupational disease or work-related accident, these should also be added to the set of documents. The whole set is then presented to the territorial division of the National Insurance Institute (NII) within 10 days prior to sanatorium admission. The NII must issue a certificate for admission. With the following documents ID card, certificate in two copies, medical referral in two copies, medical records with current and past health status - the patient can be admitted to a sanatorium (Терзиева, http://www.dnesbg.com/obshtestvo/v-51-sanatoriuma-priemat-bolni-po-programite-na-noi.html).

\subsection{Analysis of research results of scientific problems. Bulgarian balneotourism proposition}

Bulgaria "wins" foreign tourists with optimal prices for the specialized balneological programs, offering a large number of physiotherapeutic procedures. For example, the Pomorie resort has been successfully promoted for over 20 years by the German tour operator $C \& K$ Neckermann as a healing mud resort, emphasizing the long lasting use of lime mud, its healing properties and various spa programs for people with diseases of the musculoskeletal apparatus.

The analyzed data and existing natural resources allow for several suggestions aimed at extending the balneotourist season (due to favourable environment conditions and objectively available MTBs) and making more effective use of the bio-climatic resources for recreation, treatment and prevention of a number of socially significant diseases.

Balneological procedures as a specialized form of medical treatment and related balneotourism in Bulgaria have a long tradition. Well-trained specialists are employed at the national balneocenters, while various additional medical resources are constantly made available. A wide range of curative and restorative travel programs are continuously being updated with the inclusion of exotic and regional elements, as well as modern technologies, with a clear objective to meet the modern demands of international markets. As a result, the Bulgarian Spa Resort product acquires a new qualitative dimension, aiming at a wider consumer audience - from people in need of treatment and prevention to a range of healthy people, seeking relaxation and relief from everyday stress. 
The country has officially listed 102 resorts, 34 of which of national (climate, sea mountain climate) and 68 of local importance (health, mountain climate and marine weather). Phyto- and aromatherapy has seen a success as well, utilizing the great variety of herbs and plants, as well as bee products.

\section{Conclusion}

The abundance of natural resources in the territory of Bulgaria makes it a particularly suitable destination for the development of specialized forms of tourism such as balneological. Great opportunities for this are found in the settlements of Hissar, Pavel Banya, Kyustendil, Sapareva banya, Blagoevgrad, Simitli, Dobrinishte, Banya Village, Sandanski, Rupite, Velingrad, Haskovo, Burgas, etc. In the majority of these settlements exiting facilities already specialize in the field of balneology and offer a variety of traditional and modern programs and procedures.

With the right focus and policy on national tourism, balneology and spa tourism opportunities will become successful competitive advantages (Campbell et al. 2012) for Bulgaria. When a tourist destination has competitive advantages, it is able to produce greater returns compared to its competitors and earn more profit to re-invest, thus ensuring long-term stability and superiority over competition in a given market. The available natural resources in Bulgaria can be such a source of competitive advantage and increase competitiveness based on its uniqueness (whether competitors can easily copy and implement it); flexibility (whether it can be easily adapted when the market or economic conditions change); added value (the extent to which it contributes to the added value of a product or service) and sustainability (how long it can sustain market dominance), implemented in the tourist offer of balneotourism.

\section{Acknowledgments}

The research and findings presented are a result of the authors' own investigation and have not been subject of specific funding.

\section{References}

Boekstein, M. (2014), 'From Illness to Wellness - Has Thermal Spring Health Tourism Reached a New Turning Point?', African Journal of Hospitality, Tourism and Leisure, 3 (2). Retrieved October 25, 2016 from http//:www.ajhtl.com.

Campbell, D., N. Evans and G. Stonehouse (2012), Strategic Management for Travel and Tourism. Taylor \& Francis Group.

Connel, J. (2011). Medical Tourism. Oxfordshire: CABI.

Erfurt-Cooper, P. and M. Cooper (2009), Health and Wellness Tourism - SPAs and Hot Springs. Bristol: Channel View Publications. 
International Union of Tourism Organization (IUOTO). (1973), Health Tourism. Geneva: United Nations.

Laesser, C. (2011), 'Health Travel Motivation and Activities: Insights from a Mature Market Switzerland', Tourism Review, 66 (1/2), 83-89.

Bulgarian Association of balneo tourism home page. Retrieved May 5, 2016 from http://bab-bg.eu. Балнеотуризъм, Retrieved 07 of May 2016 from http://pochivka.com/.

Вода + лекари = медицински туризъм. Retrieved May 5, 2016 from http://www.trud.bg/Article. asp?ArticleId=2045129, publication of 10.06.2013.

Едрева, В. (2005), Минерални води SРА и балнеотуризъм в България [Mineral waters and SPA tourism in Bulgaria]. Издателство КРАС.

Рехабилитация и балнеотуризъм. Министерство на Здравеопазването на Република България. Retrieved 07 of May 2016 from the home page of Bulgarian Ministry of Health, http://www. mh.government.bg/bg/informaciya-za-grazhdani/rehabilitaciya-i-balneoturizm/informaciya-za-polzvane-na-bazite-za-rehabilitaciya/.

Терзиева, Б. В 51 санаториума приемат болни по програмите на НОИ Retrieved May 5, 2016 from http://www.dnesbg.com/obshtestvo/v-51-sanatoriuma-priemat-bolni-po-programite-na-noi.html. 